\title{
DIGITIZING GALICIA: \\ Cultural Policies and TRENDS \\ in Cultural Heritage Management
}

\author{
EkATERina Volkova \\ University of Auckland
}

AвSTRACT: Cultural policies have developed in Galicia significantly since the establishment of the 1981 Statute of Galician Autonomy. The Galician government has played a key role in the Galician cultural scene. However, the civil and, especially, private sectors have made a substantial contribution to the promotion of different areas of Galician culture. This article presents an overview of Galician cultural policies focusing on the area of cultural heritage management in the global era, particularly on the uses of new information and communication technologies and digitization.

Keywords: Cultural policy; cultural heritage; digitization; Xunta de Galicia; Galiciana, Afundación, ABANCA.

\section{Galicia dixital: Políticas culturais e tendencias NA XESTIÓN DO LEGADO CULTURAL}

Resumo: En Galicia, as políticas culturais desenvolvéronse de maneira significativa desde o establecemento do Estatuto de Autonomía de Galicia de 198I. O goberno galego veu xogando un papel fundamental na escena cultural. Porén, os sectores civil e, nomeadamente, o privado fixeron contribucións substanciais na promoción de diferentes áreas da cultura galega. Este artigo ofrece unha panorámica das políticas culturais centrándose no ámbito da xestión do legado cultural na era global, particularmente no referente ao emprego das novas tecnoloxías da información e a comunicación e dixitalización.

Palavras chave: Política cultural; legado cultural; dixitalización; Xunta de Galicia; Galiciana, Afundación, ABANCA.

«Adiós ríos, adiós fontes; adiós, regatos pequenos; adiós, vista dos meus ollos, non sei cándo nos veremos»—-the lines from Cantares Gallegos, a landmark of Galician culture-was displayed on computer screens and smartphones around the world on February 24, 2015. That day Google Doodles paid tribute to Galician writer Rosalía de Castro for her i78th birthday, setting her portrait against the Galician landscape and changing the first letter "o" of "Google" 
into the coat of arms of Galicia. It was a sign that Galician culture had gone global.

The global age is a period characterized by the sense of interconnectedness of all human beings and their activities due to the effects of economic, technological and cultural globalization (Albrow 20I2). Globalization has become possible because of revolutionary technological advances in communication, especially in digital information transfers (Langhorne 200I: 2). Therefore, the global age is the digital age as well. Expanding exponentially since the I990s, information and communication technologies have deeply affected every single facet of human activity, including culture and cultural policies. Digitization has transformed the cultural world, producing new types of genres, media and forms of creativity. It has created a substantial digitized cultural content and has become a vital instrument in the preservation and dissemination of cultural heritage.

Over the last decades, the concept of cultural heritage has evolved. In the I970s, UNESCO included in this category mostly tangible elements: monuments, artefacts and sites of outstanding universal value from the point of view of history, art, or science (1972). In the beginning of the $2 \mathrm{I}^{\text {st }}$ century UNESCO extended the concept of cultural heritage further, to include intangible cultural heritage and digital heritage. The category of intangible cultural heritage incorporated cultural practices, representations, expressions, knowledge, and skills (UNESCO 2003a). Digital heritage was defined as consisting of cultural, educational, scientific, and administrative resources, as well as technical, legal, medical and other kinds of information created digitally, or converted into digital form from existing analogue resources (UNESCO 2003 b).

The Universal Declaration of Human Rights states that everyone has the right to participate freely in the cultural life of the community (United Nations 1948). Beginning from the late ig6os, UNESCO started to conceptualize a special category of human rights, namely cultural rights (1970: 9-10). Since then, UNESCO and other cultural international organizations have released a number of documents, one of which in particular, the Fribourg Declaration on Cultural Rights, presented the basic principles regarding cultural rights in a concise and precise manner. This document states that the right to access cultural heritage of any kind forms an integral part of cultural rights. It indicates that the actors in the three social sectors-public, civil, and private-implement cultural rights at the local, national, regional, and international levels. The public sector comprises governments and their institutions, the civil sec- 
tor includes non-governmental and non-profit organizations, and the private sector mostly consists of commercial enterprises. All cultural agents participate in the production and distribution of cultural goods and services, while governments and their institutions have additional duties to incorporate cultural rights into legislation and elaborate cultural policy (UNESCO 2007: 4, 6-7, 9-10).

Cultural policy is mainly understood as a set of propositions and actions implemented by governments for the promotion and support of cultural practices and values. Cultural policy, similar to cultural heritage, is also a changing concept. Traditionally concerned with providing support for the arts and cultural heritage institutions, it has expanded and now includes areas such as cultural industries, urban development, and tourism, encompassing a wide range of cultural products (Throsby 2010: 8, I4-I6). The models of cultural policies differ significantly in each national or regional case, generally ascribing to four different types: the "patron", the "architect", the "engineer" and the "facilitator" (Craik 2007: I-2).

States acting as "patron" offer support to cultural industries following the principle of cultural excellence. It may be done directly or through independent bodies, making recommendations based on peer evaluation. The UK, Canada, Australia and New Zealand have employed this model. Under the "architect" type, epitomized by many Western European countries, the government acts more directly, normally through ministries of culture, which are designed to ensure access to cultural products for the public, and tends to subsidize those artists, cultural institutions and ventures whose ideological and aesthetic position aligns with national objectives. The "facilitator" type is based on the competitive market economy and private philanthropy. An example is the United States, where cultural promotion is mainly achieved through tax benefits for donors. Finally, the "engineer" type embodies the politicized model when governments exercise total control over cultural production, like in the former Soviet Union (Craik 2007: I-2). Any specific cases of cultural policy will vary depending on the political and social contexts. What follows is a study of the contemporary cultural policies of Galicia with a focus on the preservation and distribution of cultural heritage, especially on the use of digitization and the visibility of Galician culture in cyberspace.

The development of cultural policy in Galicia is a relatively recent phenomenon. Up to the end of Franco's dictatorship, Galicia had been under tight political and administrative control by the centralized Spanish state and 
this situation resulted in the historical deficit of Galician cultural institutions (Lage et al. 20ı2: in6). The institutional consolidation of Galician culture occurred only after the establishment of the 1981 Statute of Galician Autonomy. In 1982 , the Spanish state transferred all the functions and services in the area of Galician culture to the autonomous community (Real Decreto 2434/1982). Since then, the Galician government has had almost exclusive authority in the cultural arena, including the management of museums, galleries, cultural industries and the protection of cultural heritage (Miguélez-Carballeira 20I3: I76). However, private and civil actors also have played a significant role in the cultural scene of Galicia.

Cultural policies depend on the political context; therefore, it is important to call to mind the overall picture of the Galician political stage. The first years of autonomy were characterized by the unstable coalitions of various political parties (Máiz and Losada 2000: 65). From 1989, the Partido Popular (PP) has dominated the political scene of Galicia. This conservative-right political party is known for its moderate form of Galicianism and general loyalty to the Spanish central state (Fernández-Rodríguez 2016: 85). The PP was in power between 1990 and 2005, with Manuel Fraga Iribarne as president of the Xunta, and then returned to government in 2009 with current president Alberto Núñez Feijóo. The other most important political parties are the center-left Partido dos Socialistas de Galicia (PSdeG); the Galician affiliate of the PSOE, Partido Socialista Obrero Español, and the left-wing nationalist party Bloque Nacionalista Galego (BNG). The PSdeG and the BNG were in power from 2005 to 2009 , forming a coalition government. ${ }^{1}$ All the main Galician political parties present themselves as galeguistas, however, the PP has been often criticized by the opposition for its non-adequate strategies and non-sufficient efforts with respect to the commitment to the Galician language and culture.

In 1983 , the important Law of Linguistic Normalization established Galician as the official language and stipulated its institutional promotion. Since then, linguistic normalization has always been on top of the agenda of Gali-

- The traditional political map of Galicia has recently changed with the appearance of new political players. In the municipal elections of 2015, several left-wing Galician parties and movements, including Podemos, Esquerda Unida and Anova, formed the coalition En Marea, which achieved impressive results in such cities as A Coruña, Santiago and Ferrol. Subsequently, En Marea registered as a political party and in the 2016 Parliament Elections overtook the BNG and obtained the same number of seats as the PSdeG.

Abriu, 7 (2018): 25-45

ISSN: 2014-8526, e-ISSN: 2014-8534 
cian cultural policy. Although significant progress has been attained in this area, critics insist that this key component of Galician cultural policy has not been seriously addressed by the government and suggest its «obvious failure» under the PP in power (Miguélez-Carballeira 20I3:I77-I79). Galician activists have also attacked the attitude of Fraga's government towards Galician cultural heritage and cultural industries. Before 2005, the Xunta de Galicia had focused mostly on the monumental and traditional aspects of Galician cultural heritage, especially on the Camiño de Santiago and the Xacobeo celebrations, while maintaining old-fashioned stereotypes of rural Galicia, such as idyllic landscapes, bagpipes, folkloric dances, etcetera. Considering contemporary cultural industries and new technologies not "Galician enough", the Xunta did not provide them satisfactory support (Reimóndez 2011: 194-96). The rise to power of the socialist-nationalist coalition in 2005 noticeably altered the Xunta's policies for cultural industries. For example, the specially created agency, Axencia Audiovisual Galega, generated new programmes of subsidies and grants to assist creators, rather than producers as in the past, which bore fruit and generated a new wave of contemporary Galician artists. ${ }^{2}$ Yet, the situation changed again after the financial crisis of 2008 and the return of the PP to governance in 2009 (Colmeiro 20I7: I75-I76). Although this essay does not focus on the policies on linguistic normalization or the general support of the cultural industries in Galicia, it is useful to keep in mind these facts as a historical background for the discussion of cultural heritage management.

Returning to the first years of Galician autonomy, the 1981 Statute laid the foundations for the cultural policies in Galicia. The Statute proclaimed the protection and promotion of the cultural values of Galician people and also required the creation of the special institution Consello da Cultura Galega (Ley Orgánica I/I98I). This governmental organization was created in 1983 and has played a fundamental role in the institutional consolidation of Galician culture, in parallel with the Xunta de Galicia. Likewise, the Centro Superior Bibliográfico de Galicia was established in 1989, which would later become the Biblioteca de Galicia, the leading governmental institution in the management of the Galician bibliographical heritage. The Law of the Cultural Heritage of Galicia

2 Many of the filmmakers from this generation, such as Lois Patiño, Oliver Laxe, Xurxo Chirro, Peque Varela and others, epitomize the most innovative trends in Galician cinema, the so called Novo Cinema Galego, which has received considerable attention in international circuits (Colmeiro 2017).

Abriu, 7 (2018): 25-45

ISSN: $2014-8526$, e-ISSN: 2014-8534 
was subsequently passed in 1995. This legal instrument defined the cultural heritage of Galicia as constituted by all tangible and intangible assets of recognized value, which are considered of relevant interest for Galician cultural identity over time. This document also established a special heritage register, Bens de interese cultural, which refers to the most important assets of Galician cultural heritage declared and registered by the Xunta (Lei 8/1995).

In 1999, the Parliament of Galicia initiated an ambitious project in Santiago, the Cidade da Cultura de Galicia, which would become the most controversial venture of the Galician cultural policy. The Cidade da Cultura was conceived as a Galician cultural enterprise with spectacular global aspirations, similar to the Basque and Catalan projects: the Guggenheim Museum in Bilbao and the Olympic Games in Barcelona. However, being an enormous burden for the budget of Galicia, this monumental venture has been severely criticized as a vanity enterprise of the former president Fraga. 3 The works started in 200 I and the main part of this large-scale cultural hub on Mount Gaiás finally opened in 20 I. Because of the effects of the global financial crisis, the construction of the final two planned buildings was stopped in 2012 and definitively cancelled in 20I3. Nevertheless, the Cidade da Cultura is currently a remarkable repository of Galician cultural heritage and hosts two important institutions, the Library of Galicia (http://bibliotecadegalicia.xunta. gal) and the Archive of Galicia (http://arquivosdegalicia.xunta.gal). Furthermore, since 20ri, the Cidade da Cultura is home to the Centro de Proceso de Datos Integral, the digital heart of Galicia.

The creation of the World Wide Web in r99i formed the basis of a new type of global networked communication. The first catalogue of Galician web pages was published in 1999. Among them were the web sites of the Xunta de Galicia and the Consello da Cultura Galega created in I998 (Gago Mariño 2015: 185,187$)$. By the beginning of the $2 \mathrm{I}^{\text {st }}$ century, digital media technologies became firmly entrenched in everyday social practices. The Law of Information Society Services and Electronic Commerce established in 2002 the legal framework for the use of digital technologies and electronic commerce in Spain (Ley 34/2002). It was also the same year the Galician Institute of Statistics started collecting data about the new realities of the Information Society in Galicia.

3 For a variety of critical responses among Galician cultural figures, see Colmeiro 2013.

Abriu, 7 (2018): 25-45

ISSN: 2014-8526, e-ISSN: 2014-8534 
In the 2000 s, the intersection of the cultural sphere and digital technologies became a widespread reality and made its way into the international legislation. UNESCO encouraged member states to maximize accessibility to digital heritage and to create appropriate legal and institutional frameworks to secure its protection (2003 b). The Commission of the European Communities, in its turn, recommended that member states should put efforts into the digitization of analogue materials in archives, libraries and museums at local and European levels, encouraging partnerships between cultural institutions and the private sector (2006).

Another developing trend at the beginning of the $2 \mathrm{I}^{\text {st }}$ century was the new type of mass global communications. With the spread of the Internet and wireless technologies, a new horizontal form of interactive communication emerged, characterized by the capacity of sending messages from many to many. The most notable outcome was the explosion of social network sites, such as Facebook, Twitter, YouTube, Instagram, and others. Social media became platforms not only for interpersonal communication, but also for all kinds of pursuits, including socio-political and cultural activities (Castells 2013: 78, 25).

Clearly, all these global trends have found their expression in the institutional cultural environment of Galicia. The official website of the leading cultural organization Consello da Cultura Galega (http://consellodacultura.gal) is currently a multilevel and complex web portal with wide-ranging content reflecting the main directions of the Consello departments, including language, literature, communication, music, visual and performing arts. This web portal provides useful information about some innovative projects of the Consello, such as the series of «Álbums», which play a substantial role as channels of dissemination of different aspects of Galician culture. Thus, the «Álbum da Ciencia» offers biographies and bibliographical resources about significant researchers in the history of Galicia; the «Álbum de mulleres» makes visible the contributions of Galician women to culture and society, and "Vento que zoa" provides information about Galician composers. The Consello da Cultura is also in charge of some important public archives, both in physical and digital forms. The Arquivo da Emigración Galega gathers historical documents related to the phenomenon of Galician migration; the Centro de Documentación Sociolinguiistica de Galicia conserves materials linked to the language planning in Galicia, and the Arquivo Sonoro de Galicia keeps all types of audio recordings connected to Galician culture, including the voices of Galician notables, as well as songs, radio broadcasts and ethnographic audio records. 
The digitization and virtual archival of historical magazines, academic publications and private documents are important areas of activity for the Consello. Such is the case of the complete digitized collection of Céltiga, a publication of huge importance for Galician culture, published by the Galician diaspora in Buenos Aires between 1924 and 1932. Other singular projects include «Epistolarios», a consolidated electronic repository of the personal correspondence of prominent figures of Galician culture, such as Rosalía de Castro, Luís Seoane and Ramón Piñeiro, and «A Saia: Hemeroteca feminista galega», coordinated with the Centre Dona $i$ Literatura at the Universitat de Barcelona, which offers a collection of historically important Galician feminist publications. Likewise, a variety of digitized documents and hundreds of other electronic files related to Galician culture are available on-line through the Medioteca, a virtual multimedia library.

The Consello da Cultura created another web portal in 2000, Culturagalega (http://www.culturagalega.org), a comprehensive web space about Galician contemporary cultural production, philosophy, women and science, which is organized into thematic sub portals. For example, AVG is dedicated to audio-visual production, $\mathrm{LG}_{3}$ to literature, MeGA to music, Banda Diseñada to comics and graphic novels, SETESTRELO to science, and ATALAIA to contemporary art. Hence, Culturagalega consolidates information about particular Galician figures, organizations and cultural products, serving, therefore, as an extensive database for contemporary Galician culture (Gago Mariño 2015: I88).

The ministry of the Xunta responsible for the establishment of cultural policies is the Consellería de Cultura, Educación e Ordenación Universitaria. The official website of the ministry is the portal Cultura de Galicia (https:// www.cultura.gal). Similar to the web portal Culturagalega discussed above, Cultura de Galicia aggregates information about Galician cultural industries; however, their content does not overlap. While Culturagalega concentrates on individual artists and creators, Cultura de Galicia focuses on institutions of cultural industries, led by the Axencia Galega de Industrias Culturais (AGADIC), http://www.agadic.gal. AGADIC is an organization that supervises Galician cinema, drama, music and choreography institutions, and monitors the distribution of Galician cultural products on the internal and external markets. Cultural heritage is another important component of the web-portal Cultura de Galicia, which provides news regarding the Bens de Interese Cultural and links to the depositories of Galician culture, such as archives, libraries and museums. Additionally, almost all Galician public cultural organiza- 
tions share the information about their activities through their official channels on Facebook, Twitter, YouTube and other social media. Mobile applications have been also widely employed by Galician cultural organizations. For example, among more than twenty mobile applications of the Xunta, there is «Axenda Cultural», a mobile version of Cultura de Galicia, an entertainment and cultural guide available for the platforms Android and iOs.

The digitization of Galicia's cultural heritage has become in recent years a cultural project of high priority, which the Galician government carries out in alignment with current European cultural policies. The digitization of culture in Europe has experienced remarkable development in recent years. In 2008, the European Commission launched the project «Europeana», Europe's digital library, archive, and museum. The web portal Europeana Collections (http://www.europeana.eu/portal) provides free access to a wide array of digital content including books, journals, films, maps, photos, artworks, museum objects, and music. The European Commission has asked member states to strengthen efforts at further digitization of their cultural heritage, to make it visible and accessible to citizens and to import digitized items into the portal. The member states and their cultural institutions were also encouraged to involve private actors, as the projected cost of digitizing Europe's cultural heritage would be too high and could not be covered by public funding alone (201 I). Some member states contribute to the development of Europeana by means of national aggregators, such as Hispana, a portal of digital culture of Spain (http://hispana.mcu.es). In its turn, Hispana combines digital collections of the archives, libraries, museums and foundations from Spain. One of the latest contributors in Hispana was Galiciana, the digital library and archive of Galicia (http://biblioteca.galiciana.gal).

Galiciana depends on the Secretaría Xeral de Cultura, a department of the Consellería de Cultura, Educación e Ordenación Universitaria, and is managed by the Biblioteca de Galicia. In addition to the collection of the Biblioteca de Galicia, Galiciana integrates digitized works originating from other cultural institutions. Galiciana is one of the initiatives under the project «Memoria Dixital de Galicia», a new model of management and conservation of digital resources related to Galicia's material and immaterial heritage. This project, based on information and communication technologies of preservation, dissemination and accessibility, is implemented by the Consellería de Cultura for the AMTEGA, the Agency of the Technological Modernization of Galicia (https://amtega.xunta.gal), also a department of the Xunta. At this mo- 
ment, Galiciana is the main platform for the digitized cultural heritage of Galicia, which acts as a virtual depository, where public, civil and private contributors are encouraged to share their cultural resources. The digital data is physically stored at the Centro de Proceso de Datos Integral, located at the Cidade da Cultura in Santiago.

Another step towards greater visibility and accessibility of Galician cultural heritage in global cyberspace was the recent Law of Cultural Heritage passed in 20I6, which establishes new regulations, especially regarding Bens de interese cultural. This law simplifies the administrative procedures for the inclusion of cultural heritage assets into the Catálogo do Patrimonio Cultural de Galicia, requiring their digitalization and the dissemination of information about Bens de interese cultural by means of communication technologies. Furthermore, Galician museums are now required to offer their catalogues in digital form as open access (Lei 5/2016).

Some socio-cultural Internet initiatives by the Galician government clearly demonstrate a close connection between cultural policies and political context. In 2005, the Consellería da Emigración, the department of the Xunta responsible for relations with the Galician diaspora, launched the web portal GaliciaAberta (http://emigracion.xunta.gal), a project designated to strengthen the connection with Galicians living outside Galicia, especially in cities with historical large-scale Galician migration, including Buenos Aires, Montevideo and Geneva. It is important to remember that a significant percentage of Galician voters live abroad and traditionally have voted predominantly for the Partido Popular, which has actively courted this part of the electorate (Gemie 2006: 130$)^{4}$. Prior to the 2005 Galician elections, the PP had been in power for I 5 years. However, due to the crisis in Galician society following the 2002 ecological disaster of the oil tanker Prestige, the PP started losing the support of their potential voters (Gemie 2006: I76). In 2004, the Xunta issued a legal document modifying the 1985 Law of elections to increase the participation of the Galician electorate residing abroad (Ley I2/2004) ${ }^{5}$. This context suggests that the creation of the web portal GaliciaAberta on the eve of the Parliament

4 In the Parliament Elections of $200 \mathrm{I}$ in Galicia, the Electoral Census of Absent Residents counted 268,452 voters, about 10.5\% of the total enrolment roll (INE 200I).

5 In the Parliament Elections of 2005 in Galicia, this number reached 305,019 voters, approximately I2.5\% (INE 2005). This trend has continued and in 2016 this index increased up to 446,270 voters, approximately 16.5\% (INE 2016).

Abriu, 7 (2018): 25-45

ISSN: 2014-8526, e-ISSN: 2014-8534 
Elections of 2005 , besides its socio-cultural purposes, had clear political goals, attracting potential voters of the PP.

So far, my article has centred on the public institutions of Galicia. With respect to the civil actors on the Galician cultural stage, it is crucial to discuss the role played by the association PuntoGal, a non-profit organization that managed to obtain an Internet top-level domain for Galician society. The world organization responsible for the management of top-level domains, identifying all web resources, is the Internet Corporation for Assigned Names and Numbers, ICANN. The recognized two-letter codes corresponding to a country, territory, or other geographic location come from United Nations official sources (ISO n.d.), and stateless nations such as Scotland, Catalonia or Galicia, are not present on this list. This situation motivated the Catalan-speaking Internet community in the I990s to express its aspiration to possess its own internet domain. The long public campaign succeeded and led to the approval by ICANN in 2005 of the domain .cat. The creation of .cat inspired the Galician Internet community and in 2006 a number of Galician institutions promoted the establishment of the Asociación PuntoGal, whose main objective was to obtain for Galician language and culture the domain .gal. This was achieved in 2013 when the top-level domain gal was approved by ICANN. The first web page with this domain (www.dominio.gal) was activated in May 20I4. This event was characterized by Galician media as the «collective success of the whole Galician society» and as a «historical milestone that raised the Galician flag in Internet» (El País 2014, my translation). In 2015 the Xunta of Galicia issued a decree, by which all the departments of the Xunta, its portals and dependent organizations, would use the domain .gal (Decreto 74/2015). The Asociación PuntoGal encourages Galician companies to use the domain .gal for the purpose of representation of Galician language and culture in cyberspace and promotion of the global visibility of Galician society.

Besides the central role played by public cultural institutions, non-governmental and civil organizations also participate in the digitization of Galician cultural heritage. Among them is the Fundación Castelao, created by volunteers in 1984 with the purpose of recovering the rich cultural heritage of Alfonso Daniel Rodríguez Castelao, a writer, politician, artist, and the most important Galician nationalist intellectual of the $20^{\text {th }}$ century. Due to his nationalist ideology, the figure of Castelao has always provoked mixed reactions from the different groups in the contemporary Galician political stage. In 1984, through the initiative of the centrist coalition that held power at that time, the remains 
of Castelao were returned from Argentina to Galicia and were buried in Santiago de Compostela in the Panteón de Galegos Ilustres, where the mortal remains of other distinguished Galician cultural figures such as Rosalía de Castro are laid to rest. Galician nationalists, for whom Castelao has been an iconic figure, accused the Xunta of appropriating their political discourse (Medeiros 20I3: 44). Since the nationalist political views of Castelao differ in fundamental ways from the loyal position towards the Spanish state of the Partido Popular, this party did not show much support for the Fundación Castelao. During the PP governance in the I990s, the foundation carried out the labour of finding and systematizing Castelao's texts and visual works, mostly relying on its own resources and private organizations. Thus, their collaboration with the editorial house Galaxia led to the publication of Castelao's written works in six volumes in 2000 . However, in a different political climate, in 2008 the foundation obtained financial support from the Xunta, controlled at that time by the coalition between the PSdeG and BNG, and started the digitization of Castelao's graphic works. By 20 ıo the Fundación Castelao had recovered and digitized 3,800 items and made them available online on its own website (http://fundacioncastelao.gal) and through the website of the Biblioteca de Galicia (Código Cero 20I0: 30); at present these materials are available on the portal Galiciana. The current strategy of the Xunta with respect to Castelao is ambivalent. According to president Feijóo, Castelao is a «valid symbol», because «he was primarily a humanist above his political stance» (cited in Lombao 20I4, my translation). Thus, in $20 \mathrm{I} 4$ with the purpose of celebrating the $70^{\text {th }}$ anniversary of the publication of Castelao's foundational text Sempre en Galiza, the Consello da Cultura published on its social network sites one quote from this book every day, over two months. The Consello also encouraged all Internet users to contribute to this project and to post on their private social network accounts other phrases from Sempre en Galiza and/or their reflections on Castelao and his work, accompanied with the hashtag \#sempreengz. Moreover, in collaboration with the publisher Galaxia and the University of Santiago de Compostela, the Consello launched the free mobile application «SempreenGZ». This continually changing policy towards Castelao' legacy illustrates how cultural capital may be manipulated, negated or appropriated by political parties depending on their current needs.

Within the discussion of the role of civil actors in Galician culture, it is important to note that civil cultural activism frequently develops on the margins of official institutions, and that its reach can have global dimensions be- 
yond the immediate geopolitical coordinates, such as the recent campaign in defence of the economically challenged Centro Gallego in Buenos Aires organized trough the digital platform Change.org ("Salvemos o Centro Galego de Bos Aires!") and the Facebook group ("Hay que salvar al Centro Gallego de Buenos Aires”). Since 1907, the Centro Gallego in Buenos Aires has been an iconic organization for the Galician diaspora, which has provided support and medical assistance for Galician immigrants and, at the same time, has become an emblematic site of Galician culture overseas. The centre holds highly valuable assets of Galician cultural heritage in its library and art collection of prominent $20^{\text {th }}$ century Galician artists. Due to the economic difficulties and after the Xunta had dissociated from the Centro in 20II, in December of 20 I7 the members of the Centro approved the sale of the assets to Ribera Salud, the Spanish giant of private health services (S.V. 20I7), with the professed intent of maintaining direct management of the Galician cultural heritage in Argentina. While the Xunta has stated that the Galician government will respect this decision and will lend its support to the protection of cultural heritage (Faro de Vigo 2018), leading figures of contemporary Galician culture have issued a manifesto through Change.org ("Manifesto pola defensa e porvir do Centro Galego de Bos Aires"), urging the Galician government to take proactive measures against the danger of the disappearance of the artistic and bibliographic heritage of the Centro (Villar 20I8). This case illustrates the far-reaching international dimensions of Galician cultural heritage, the pressures of global neoliberalism, and the important role that social media and digital communication have acquired in Galicia for contemporary civil cultural activism.

The next section describes the role that the Galician private sector has played in cultural programmes. It is well known that before the global financial crisis of 2008, the most important private cultural agents in Galicia were two savings banks, Caixa Galicia and Caixanova (Lage et al. 2012: 133). Their respective art and book collections, which are of huge importance for the cultural heritage of Galicia, are now owned by the newly created bank corporation ABANCA, following a complicated and highly politicized merging process. Spanish savings banks were originally financial institutions that traditionally specialized in financial services for a broad cross-section of the population, including people with low incomes and from rural areas, and were normally under governmental control. Their mission was also to carry out philanthropic ventures, the so-called Obra social, with the aim of conducting sociocultural 
activities in the region in which they operated (Martín-Aceña 20I3: 87, 9I). Both Caixa Galicia and Caixanova developed significant programmes of Obra social, which include their important art and book collections.

The Caixanova art collection was in great part derived from the substantial holdings of the Obra social gathered by the former savings bank from Vigo, Caixavigo. This pioneering collection started in the rg6os and coincided with the period of re-emergence of interest towards Galician culture, still under the Franco dictatorship. That period was marked by the development of important new cultural initiatives by anti-Franco activists and Galician nationalists, for instance, the foundation of the Galician language publishing house Galaxia and the establishment of the Day of Galician Letters. The purpose of the Caixavigo art collection was timely and innovative: to support Galician artists, many returning from exile, and to disseminate knowledge about Galician culture, neglected by the regime (J.L. 2009). The savings bank Caixanova, launched as a result of the merging of Caixavigo with the Southern Galicia savings banks of Pontevedra and Ourense in 2000, established its own foundation, Fundación Caixanova, and continued expanding the art collection. The Caixanova Collection thus became one of the most prominent art collections held by a financial institution in Spain, containing works of many media formats, mostly from Galicia, but also with works of Spanish and international artists.

The savings bank Caixa Galicia was founded in 1978 as a result of the merging of the Northern Galicia savings banks of A Coruña, Lugo, Ferrol and Santiago. The Fundación Caixa Galicia was established in 1989 as a main component of its Obra social, including the collection of rare and antique books, the Fondo Bibliográfico Histórico Caixa Galicia. Caixa Galicia started its art collection much later than the other savings banks, only in 1996. However, according to some experts, Caixa Galicia acquired artworks in a professional and systematic way, and accumulated fewer items than Caixanova, but arguably of higher value (Rodríguez 2013).

The collapse of Spain's property market in 2008 caused an ongoing financial crisis and deeply affected the whole banking system of Spain and, especially, regional savings banks. In 2009, the Spanish government launched a bailout programme, targeting in particular savings banks' merges and acquisitions. Under this programme, Caixa Galicia and Caixanova merged in November 20ı, forming a new regional savings bank, Novacaixagalicia. Several months later, in 20II, Novacaixagalicia closed and all its assets and liabilities were transferred to the bank NCG Banco S.A. with the commercial name Novagalicia Banco. 
This new bank was soon nationalised by the Spanish government, and in December 20I4 was sold at auction to the private bank from Venezuela, Banesco. The new bank received the new trade name ABANCA Corporación Bancaria. The Galician opposition in 2013 attacked the Xunta for the support it had given to the decision made by the Spanish Ministry of Economy to sell the NCG Banco to a foreign investor. The BNG urged the Galician government to pass a law and to stop the sale. One of the main preoccupations of the Galician opposition was the destiny of the art collections of former Caixa Galicia and Caixanova. Concerned about preventing Galician heritage from leaving Galicia and maintaining public access, the BNG even suggested transporting the former collection from Vigo to the recently opened Cidade da Cultura. However, this proposition was firmly rejected not only by the PP but also the PSdeG, and met extremely negative reactions from the authorities of Vigo. The Xunta de Galicia in October 2013 assured that the collections would remain in their current places and that the Xunta would start the process of registering the collections as Bens de interese cultural. The BNG, in its turn, argued that these measures would not guarantee the artworks remaining in Galicia, continuing to criticize the Xunta for the absence of effective actions.

At the time of the merger, the Caixanova art collection contained 5,596 art pieces, while Caixa Galicia had I,350 art works and 3,200 items in the bibliographical collection. Today, the two collections remain separate due to their different purchasing processes, as well as their historical attachment to the respective cities of origin. The Caixanova art collection had been acquired from the funds of the Obra social, and thus belonged to the public foundation, the Fundación Novacaixagalicia. On the other hand, Caixa Galicia had recorded its art acquisitions as investments, and therefore the contents of this collection became assets of Novagalicia Banco (Pousa 2013; Bascoy 2013). Nowadays, the former collection of Caixanova is known as the collection Afundación, registered as property of the Fundación Galicia Obra Social; and the former art collection of Caixa Galicia is known as the collection ABANCA, registered as property of this banking corporation. In October 20I5, after the authorities of ABANCA gave their permission, the Xunta declared as Bens de interese cultural both the ABANCA and Afundación art collections, highlighting their status as important protected elements of the rich Galician cultural heritage (Decreto I5I/20I5, Decreto I52/2015).

These two art collections are in fact considered the most comprehensive collections of $20^{\text {th }}$ century Galician art. This artistic treasure covers such sig- 
nificant figures of modern Galician art as Sotomayor, Pérez Villaamil, Lloréns, Ovidio Murguía, Castelao, Colmeiro, Seoane, Maruja Mallo, Laxeiro, Granell, and Urbano Lugrís; it also includes such prominent Spanish and international artists as Picasso, Leger, Miró, Dalí and Braque, among others. To maximize the public accessibility to this important artistic heritage of Galicia, the artworks from both art collections are regularly shown in thematic exhibitions and as loans in museums and galleries around Galicia. Nevertheless, the major part of these collections is not permanently available for direct viewing, but only in digital form. The highlights of the art collection Afundación are put on display in the main building of the foundation in Vigo and also can be viewed online as a virtual tour through Google Maps. The webpage of the collection (https://www.afundacion.org/es/coleccion) offers access to the whole catalogue of digitized artworks, including a short biography for each artist and a description for each artwork that gives a brief art history analysis and tracks the history of its exhibitions and reproductions. The art collection ABANCA is physically stored in a special building in A Coruña constructed for this purpose. The website of ABANCA art collection, (http://coleccion.abanca.com) also offers its digitized catalogue on-line as well as a virtual tour that provides a $3 \mathrm{D}$ interactive environment which allows users to click on individual artworks for a close-up view with drop-down metadata about each artwork. The bibliographical collection ABANCA is another important piece of the Galician cultural heritage, the most valuable part of which are its 66 incunabula, with its oldest treasure dating back to I47I. In 20I4 ABANCA allowed its collection of books and documents to be stored in the Biblioteca de Galicia at the Cidade da Cultura, which immediately started the process of digitization of incunabula. These are now accessible through the portal Galiciana that allows users to virtually flick through books more than 500 years old. The following year this collection was declared as Ben de interese cultural (Decreto I13/2015). As a result of these developments, these important artistic and bibliographical Galician collections assembled by private financial institutions have acquired a legal status as protected Galician cultural heritage and they have also become more easily accessible to the public thanks to the deployment of digital technologies.

Concluding the brief overview of the Galician cultural policies in the area of cultural heritage and visibility of Galician culture, it is possible to make the following observations: the model of Galician cultural policy is likely to be generally ascribed to the "architect" type, because the Consellería de Cultura 
of the Xunta de Galicia and its dependent cultural organizations, such as public foundations, associations, libraries, museums and archives, have been the key actors in the implementation of cultural policies in Galicia. Here it is worth noting that the Consello da Cultura, a fundamental public institution for Galician culture, in spite of acting independently with respect to the powers of Galicia, also depends financially on the Xunta de Galicia. Nevertheless, the non-governmental and private organizations have also played a significant role in the Galician cultural scene. Especially important have been the cultural programmes of the major financial institutions, particularly, the banking corporation ABANCA and its predecessors.

Since 198I, when the Statute of Galician Autonomy marked the starting point of the official cultural policy in Galicia, the autonomous government has achieved significant results in the management of cultural heritage, including the relevant legislation and the register for Bens de interese cultural. A number of measures implemented under the cultural policies of the Xunta de Galicia ensures the cultural rights of Galician people to access their heritage. However, the general examination of the Galician context reveals certain weak sides in the existing model of cultural policy. Thus, the priority that is given to certain projects is inevitably affected by the political power structures and their own interests. Besides, the extensive degree of public intervention creates an excessive dependence of Galician cultural organizations and industries on the support of the Xunta de Galicia, which makes them particularly vulnerable to political and economic fluctuations, as in the circumstances of financial crisis, when the government drastically reduced or shifted the funding of many cultural projects. At the same time, private actors, although often collaborating with the Xunta and its cultural policies, tend to act rather independently and so their contribution to the creation, preservation and dissemination of Galician cultural heritage depends for the most part on the interests of such organizations.

Nevertheless, whatever models of cultural policy are involved, it is obvious that digital technologies have become indispensable instruments of the cultural policy in Galicia in the area of cultural heritage. Without replacing traditional forms, the Internet provides additional and almost unlimited capacity for the visibility of Galician culture. The digitization of cultural heritage, which is nowadays embedded into Galician legislation, is highly beneficial for Galician culture and the promotion of values of the Galician people. It contributes to the development of Galician identity at large, facilitating partic- 
ipation in cultural activity of much a wider cross-section of people, thus making cultural heritage less elitist and much more accessible, both to Galicians and to the world at large. The digitization of Galician cultural heritage is carried out in alignment with European and international legislation practice and contributes to the maintenance and promotion of European cultural digital heritage. Without a doubt, Galician culture has gone global and it will see further developments in this direction in the years to come.

\section{WORKS CITED}

Albrow, Martin (2012). «Global age». George Ritzer (ed.), The Wiley-Blackwell Encyclopedia of Globalization. Oxford: Blackwell.

Bascoy, Irene (2013). «Dos colecciones de arte y solo una de Galicia». Faro de Vigo, I3 Oct. [online] <http://www.farodevigo.es/galicia/2013/ıo/ız/colecciones-arte-gali$\mathrm{cia} / 895047 \cdot \mathrm{html}>$.

Código Cero (20I0). «A obra gráfica de Castelao estará accesible na Rede». Código Cero $79,30$.

Colmeiro, José (20I3).Galeg@s sen fronteiras: Conversas sobre a cultura galega no século XXI. Vigo: Edicións Xerais de Galicia.

Colmeiro, José (2017). Peripheral Visions / Global Sounds: From Galicia to the World. Liverpool: Liverpool UP.

Commission of the European Communities (2006). «Commission Recommendation of 24 August 2006 on the digitisation and online accessibility of cultural material and digital preservation (2006/585/EC)». Official Journal of the European Union, 236.

Craik, Jennifer (2007). Re-visioning Arts and Cultural Policy: Current Impasses and Future Directions. Canberra: ANU E Press.

DeCRETo 74/20I5, do I3 de maio, polo que se regula a organización da presenza na internet da Administración xeral e do sector público autonómico de Galicia baixo o dominio de nivel superior .gal. Diario Oficial de Galicia, 94, 2I May 2015 [online] $<$ https://www.xunta.gal/dog/Publicados/2015/20150521/AnuncioGo244-1505150004_gl.html>.

Decreto iI $3 / 2015$, do 4 de xuño, polo que se declara ben de interese cultural o fondo bibliográfico e documental de Abanca Corporación Bancaria, S.A. Diario Oficial de Galicia, I70, 7 Sep 2015 [online] <https://www.xunta.gal/dog/Publicados/2015/20150907/AnuncioGor64-250815-000I_gl.html>.

Decreto I5I/2015, do 8 de outubro, polo que se declara Ca colección de arte de ABANCA Corporación Bancaria, S.A. Diario Oficial de Galicia, 205, 27 Oct 2015

Abriu, 7 (2018): 25-45

ISSN: $2014-8526$, e-ISSN: $2014-8534$ 
[online] <https://www.xunta.gal/dog/Publicados/2015/20151027/AnuncioGor64I91015-0004_gl.html>.

Decreto 152/2015, do 8 de outubro, polo que se declara ben de interese cultural a colección de arte da Fundación Galicia Obra Social (Afundación). Diario Oficial de Galicia, 207, 29 Oct 2015 [online] <http://www.xunta.gal/dog/Publicados/ 2015/20151029/AnuncioGor64-221015-0002_gl.html>.

El País (2014). "Nace la primera web del dominio “.gal”». El País, i6 Mar [online] $<$ http://ccaa.elpais.com/ccaa/20I4/05/I6/galicia/I4002504I3_796038.html>.

European Commission (2011). «Commission Recommendation of 27 October 20 in on the digitisation and online accessibility of cultural material and digital preservation (2011/7II/EU)». Official Journal of the European Union, 283.

FARO DE VIGO (20I8). «La Xunta respeta la decisión del Centro Gallego de mantener su patrimonio en Buenos Aires». Faro de Vigo 25 January [online] <http://www.farodevigo.es/galicia/2018/or/25/xunta-respeta-decision-centro-gallego/r82563r.html>.

Fernández Rodríguez, José Julio (2016). «The Parliament of Galicia». Guy Laforest; André Lecours (ed.), The Parliaments of Autonomous Nations. Montreal: McGillQueen's UP, 72-96.

Gago Mariño, Manuel (2015). «Cultura galega e territorios dixitais: entre a sociedade civil e as institucións». Olga Castro; María Liñeira (eds.), Trama e urda: Contribucións multidisciplinares desde os estudos galegos, Santiago de Compostela: Consello da Cultura Galega, I8I-19o.

Gemie, Sharif (2006). A concise history of Galicia. Cardiff: Wales UP.

INE (200I). «Elecciones al Parlamento de Galicia 200I». Instituto Nacional de Estadística [online]. <http://www.ine.es/jaxi/Datos.htm?path=/t44/po5/a200i/lo/\&file $=0$ ro2.px $>$.

INE (2005) «Elecciones al Parlamento de Galicia de I9 de junio de 2005». Instituto Nacional de Estadística [online] <http://www.ine.es/jaxi/Tabla.htm?path=/t44/po5/ a2005/lo/\&file $=0104 \cdot p x \& L=0>$.

INE (2016) «Elecciones al Parlamento de Galicia de 25 de septiembre de 20I6». Instituto Nacional de Estadística [online] <http://www.ine.es/jaxi/Tabla.htm?path=/ t44/po5/a2016/lo/\&file=oro4.px\&L=0>.

ISO (s. d.). «Country Codes - ISO 3166». International Organization for Standardization [online] <https://www.iso.org/iso-3i66-country-codes.html>.

J. L. (2009). «Caixanova posee la mayor colección de arte gallego». La Voz de Galicia 24 May [online] <http://www.lavozdegalicia.es/noticia/vigo/2009/05/24/caixanova-posee-mayor-coleccion-arte-gallego/0003_773766r.htm>.

Lage, Xesús; Losada Trabada, Antonio; Gómez Ocampo, Marta (2012). «La política cultural en la comunidad autónoma gallega: de la dependencia a la autonomía». RIPS, II, 3, II5-I48.[online] <http://www.usc.es/revistas/index.php/rips/article/ view/I02I $>$. 
Langhorne, Richard (200I). The Coming of Globalization: Its Evolution and Contemporary Consequences. New York: Palgrave.

LeI 8/1995, do 30 de outubro, do patrimonio cultural de Galicia. Diario Oficial de Galicia, 214, 8 Nov I995 [online] <http://www.xunta.gal/dog/Publicados/1995/1995Iro8/ Anuncio5996_gl.html>.

LeI 5/2016, do 4 de maio, do patrimonio cultural de Galicia. Diario Oficial de Galicia, 92, I6 May 2016 [online] <https:/www.xunta.gal/dog/Publicados/20r6/20r605ı6/ AnuncioC 3 Bo-110516-000I_gl.html>.

LEY 34/2002, de i de julio, de servicios de la sociedad de la información y de comercio electrónico. Boletín Oficial del Estado, I66, I2 Jun 2002. https://www.boe.es/buscar/act.php?id=BOE-A-2002-13758

LEY I2/2004, de 7 de diciembre, por la que se modifica la Ley 8/1985, de 13 de agosto, de elecciones al Parlamento de Galicia. Diario Oficial de Galicia, 243, I6 Dec 2004 [online]. <https://www.xunta.gal/dog/Publicados/2004/2004I2I6/Anuncio2ıAı__ gl.html>.

Ley Orgánica i/rg8ı, de 6 de abril, de Estatuto de Autonomía para Galicia. Boletín Oficial del Estado, Iо I, 28 Apr i98 I [online] <https://www.boe.es/buscar/doc.php? id=BOE-A-I98I-9564>.

Lombao, David (20I4). «El golpe franquista, un "capricho de la historia” para Feijóo». Eldiario.es, 28 Jun. [online] <http://www.eldiario.es/galicia/golpe-franquistacapricho-historia-Feijoo_○_275772868.html>.

Máiz, Ramon; Losada, Antón (2000). «Institutions, policies and nation building: the Galician case». Regional and Federal Studies, Iо, I, Spring, 62-91.

Martín-Aceña, Pablo (2013). «The Savings Bank crisis in Spain: When and How?». ESBG Perspectives, 66, 85-98.

Medeiros, António (2013). Two Sides of One River: Nationalism and Ethnography in Galicia and Portugal. New York: Berghahn.

Miguélez-Carballeira, Helena (2013). Galicia, a Sentimental Nation: Gender, Culture and Politics. Cardiff: Wales UP.

Pousa, Luís (2013). «El arte que sobrevivió a la fusión». La Voz de Galicia, 20 May [online] <http://www.lavozdegalicia.es/noticia/cultura/2013/05/20/arte-sobreviviofusion/0003_201305G20P2799ı.htm>.

Real Decreto 2434/1982, de 24 de julio, sobre traspaso de funciones y servicios del Estado a la Comunidad Autónoma de Galicia en materia de cultura. Boletín Oficial del Estado, 235, I Oct 1982 [online] <http://www.boe.es/buscar/doc.php?id= BOE-A-1982-25542>.

Reimóndez, María (20II). «Whose Heritage Is It, Anyway? Cultural Planning and Practice in Contemporary Galicia». Kirsty Hooper; Manuel Puga Moruxa (ed.), Contemporary Galician Cultural Studies: Between the Local and The Global, New York: MLA, 190-20I. 
Rodríguez, R. (2013). «Novagalicia, un museo más grande que el Gaiás». Economia Digital Galicia, 30 Jun. [online] <https://galicia.economiadigital.es/finanzas-ymacro/novagalicia-un-museo-mas-grande-que-el-gaias_331067_102.html>.

S. V. (2017). «El Centro Gallego de Buenos Aires será vendido al gigante español de la sanidad privada». El País ig Diciembre [online]. <https:/elpais.com/ccaa/2017/12/ Ig/galicia/ı5136988I4_632678.html>.

Throsby, David (2010). The Economics of Cultural Policy. New York: Cambridge UP. UNESCO (1970). Cultural Rights as Human Rights. Paris: UNESCO.

UNESCO (1972). Convention Concerning the Protection of the World Cultural and Natural Heritage. Paris: UNESCO.

UNESCO (2003a). Convention on the Safeguarding of the Intangible Cultural Heritage. Paris: UNESCO.

UNESCO (2003b). Charter on the Preservation of Digital Heritage. Paris: UNESCO.

UNESCO (2007). Fribourg Declaration on Cultural Rights. Geneva: Organisation Internationale de la Francophonie; UNESCO.

United Nations (1948). The Universal Declaration of Human Rights. Paris: UN.

VilLar, Carmen (2018). «Los tres rectores instan a defender el Centro Gallego de Buenos Aires». Faro de Vigo I3 Feb. http://www.farodevigo.es/galicia/2018/02/13/ tres-rectores-instan-defender-centro/I836789.html 